International Journal of Child, Youth and Family Studies (2013) 2: 189-208

\title{
“IF EVERYONE COPIES ME, THAILAND WILL BE SO MUCH BETTER OFF”: THE POWER OF VERBAL IRONY IN YOUTH CONVERSATION
}

\author{
E. Leslie Cameron, Lea Hedman, Nora Didkowsky, \\ Sombat Tapanya, and Catherine Ann Cameron
}

\begin{abstract}
This paper explores the types of verbal irony employed by resilient youth in spontaneous conversation and examines how they use this irony to navigate potentially challenging psychosocial terrain. We documented and analyzed instances of irony in the spontaneous speech of adolescent participants in an international, ecological study of resilience using quasi-naturalistic and participatory visual methods. We found irony to be co-constructively utilized by the youths we studied. They spontaneously used many types of irony to mute criticism and avoid embarrassment. These resilient youth, who were thriving under adverse circumstances, used irony in a positive way to facilitate affiliation with their friends and family.
\end{abstract}

Keywords: humor, irony, youth, resilience, interaction, visual methodology, quasiecological

Note: This project is part of a large multi-method study entitled the Negotiating Resilience Project, led by Michael Ungar, Catherine Ann Cameron, and Linda Liebenberg, funded by the Social Sciences and Humanities Research Council of Canada and housed at the Resilience Research Centre at Dalhousie University, Halifax, Canada. Information about this project is accessible at http://resilienceproject.org/

E. Leslie Cameron, Ph.D. (the Corresponding Author) is Associate Professor in the Department of Psychological Science, Carthage College, 2001 Alford Park Drive, Kenosha, Wisconsin, 53140 U.S.A. Email: lcameron@carthage.edu.

Lea Hedman, B.A. is a 2011 graduate of Carthage College, Kenosha, Wisconsin. E-mail: lhedman@carthage.edu.

Nora Didkowsky is a doctoral student in the Interdisciplinary Ph.D. Program, Dalhousie University, Halifax, Nova Scotia, Canada. E-mail: nora@gpiatlantic.org

Sombat Tapanya, Ph.D. is Retired Assistant Professor in the Psychiatry Department, Chiang Mai University, Thailand. E-mail: sombat.tapanya@gmail.com

Catherine Ann Cameron, Ph.D. is Honorary Professor of Psychology at the University of British Columbia, 2136 West Mall, Vancouver, B.C., V6T 1Z4, (604) 822-9078. E-mail: acameron@psych.ubc.ca 
International Journal of Child, Youth and Family Studies (2013) 2: 189-208

Adolescence is a time of significant personal and social growth and change. Successful navigation through this developmental period can be enhanced by the recruitment of a wide variety of psychosocial resources in ecological context (Masten \& Wright, 2010; Sameroff, 2010; Ungar, 2011; Werner \& Smith, 2001). Data from an international multi-method study of resilience (Cameron et al., in press) provides a unique opportunity to explore the use of certain resources by diverse at-risk but thriving youth.

This paper explores the use of irony in spontaneous conversation by these resilient youth and demonstrates that verbal irony is a beneficial communicative resource for navigating potentially challenging psychosocial terrain. Irony is conceptualized as a type of humor and our previous research on the development of humor (E. L. Cameron, Fox, Anderson, \& C. A. Cameron, 2010) demonstrated the use of humor by resilient youth in conversation with family members and peers. In this paper we extend our findings to demonstrate the variety of types of irony used by these youth and the functions that using irony serves. In order to situate irony in the broader context we begin with a discussion of humor and its development in children and youth. We use the term "irony” throughout the paper to refer to verbal irony.

\section{Studies of Humor}

There are a variety of definitions of humor, and many of them focus on incongruity and the element of surprise, which highlight the cognitive nature of humor. Within a cognitive framework, “canned” humor, typically jokes in which people tell relatively fixed, short stories that are amusing and end in a punch line, have been useful in exploring humor comprehension and appreciation. This type of humor is a staple in the investigation of humor in experimental settings because jokes are relatively "context-free" and "self-contained", and have within them much, if not all, the information necessary to be appreciated by a wide range of participants (Martin, 2007, p. 12).

\section{Socio-emotional Functions of Spontaneous Humor in Children and Youth}

Whereas a good deal has been learned within a cognitive framework, more recent attempts have been made to explore humor from a socio-emotional perspective (Martin, 2007, p. 9). Socio-emotional aspects of humor are better understood from spontaneous conversations in naturalistic environments in which the context is critical to the comprehension and appreciation of humor. Moreover, spontaneous conversation includes many forms of humor, jokes per se accounting for only 11\% of daily laughter (Martin \& Kuiper, 1999), and other forms of humor serve many psychosocial functions.

We have previously explored, using audiovisual methodologies, a broad range of humor types and, importantly, the socio-emotional functions of socially contextualized youth humor. We have documented examples of joking, teasing, physical play, light tones, mocking/parody, 
International Journal of Child, Youth and Family Studies (2013) 2: 189-208

and finally and relevant to the current investigation, irony and sarcasm in youth conversation (E. L. Cameron, Fox, Anderson, \& C.A. Cameron, 2010; see also E. L. Cameron, Accorti Gamannossi, Gillen, \& C. A. Cameron, 2010, for a discussion of types of toddler humor). Humor, broadly defined, scaffolds youth and young children in navigating complex, socially sensitive topics and situations, deflecting unwanted attention, protecting interlocutors, eliciting laughter and attention from others, and facilitating affiliation with friends and family. Humor assists in traversing challenging socio-emotional terrain and may serve as a facilitatory or "promotive" factor in resilience or thriving (Sameroff, 2010, p. 14), especially in delicate psychosocial situations (E. L. Cameron, Fox, Anderson, \& C. A. Cameron, 2010).

\section{Conceptualizing Irony and its Functions}

Broadly speaking, irony, a type of humor, is a complex speech act in which the intended meaning of a statement differs from its literal meaning (Martin, 2007, p. 13), and can take many configurations. According to Dews, Kaplan, and Winner (1995), "irony is characterized by opposition between two levels of meaning: The speaker's literal meaning is evaluatively the (approximate) opposite of the speaker's intended meaning” (p. 298). Colston (1997) also defined ironic speech as being non-literal because "the words used do not correspond with the meaning intended by the speaker" (p. 319).

According to Winner (1988), "an understanding of irony requires that one recognize the evaluative incongruity between what is said and what the speaker believes to be true" (p. 25), that is, that one understands and appreciates a (comic) synergy between them. Incongruity, or perhaps more aptly cognitive synergy (Apter, 1982, 2007) plays an important role in understanding irony as there is a disjunction between the real and the apparent, or the literal and non-literal meanings of the ironic utterance.

Many types of irony have been identified in the literature, which we have synthesized in Table 1. There are ironic statements that are ironic criticisms and ironic compliments (Dews et al., 1995); sarcasm, rhetorical questions, hyperbole, and understatement (Gibbs, 2000); literally false, literally true, ambiguous, or nonverbal (Winner, 1988). Pexman, Glenwright, Krol, and James (2005) outlined the complexity of comprehending irony and confirmed the need to accommodate both listener and speaker perspectives in ironic discourse. Definitions of these types of irony and examples are all provided in the second and third columns of Table 1 to provide a compilation of the types of ironic utterances already identified.

As irony allows the speaker to convey messages in an indirect/non-literal way it may serve a variety of cognitive-linguistic and socio-emotional functions as well (see Table 2), including a humorous and muting expressive modulation of communications (Dews et al., 1995). 
International Journal of Child, Youth and Family Studies (2013) 2: 189-208

\section{Table 1. Types of Irony}

\begin{tabular}{|c|c|c|c|}
\hline Types & Definitions & Examples & Examples from Youth Participants \\
\hline Ironic Criticism $^{1}$ & $\begin{array}{l}\text { "The most commonly used form of irony [is } \\
\text { one] in which the speaker says something } \\
\text { positive to convey a negative attitude." (p. } \\
298 \text { ) }\end{array}$ & “Great game” after losing a game. & $\begin{array}{l}\text { Lorraine: "Nice one" after friend has } \\
\text { mistakenly referred to the game } \\
\text { "four-square" as "foreplay". }\end{array}$ \\
\hline Ironic Compliment $^{1}$ & $\begin{array}{l}\text { “... a negative statement used to convey a } \\
\text { positive evaluation.” (p. 298) }\end{array}$ & “Terrible game” after winning a game. & $\begin{array}{l}\text { Lorraine: "You're a terrible, terrible } \\
\text { friend" when the friend does not } \\
\text { immediately agree to spend the day } \\
\text { with her. }\end{array}$ \\
\hline Jocularity $^{2}$ & $\begin{array}{l}\text { “... speakers teased one another in } \\
\text { humorous ways.” (p. 12) }\end{array}$ & $\begin{array}{l}\text { "What, wo-ah, you're dissin’ my Latin” } \\
\text { during a conversation with friends who are } \\
\text { joking about the purpose of taking a Latin } \\
\text { class. }\end{array}$ & $\begin{array}{l}\text { Neil: "I just seen him bookin’ down } \\
\text { the street” when he sees his friend } \\
\text { coming down the street. (Cameron, } \\
\text { Fox, et al., 2010) }\end{array}$ \\
\hline Sarcasm $^{2}$ & $\begin{array}{l}\text { “... speakers spoke positively to convey a } \\
\text { more negative intent”. (p. 12) }\end{array}$ & $\begin{array}{l}\text { "They bring in the most wonderful guests } \\
\text { in the world and they can totally relate to } \\
\text { us" about unpleasant guests. }\end{array}$ & $\begin{array}{l}\text { Lorraine: "Yes on you, Jerry" when } \\
\text { responding to a boy who asks if the } \\
\text { research project is actually about him. } \\
\text { (Cameron, Fox, et al., 2010) }\end{array}$ \\
\hline Rhetorical Questions $^{2}$ & $\begin{array}{l}\text { “... speakers literally asked a question that } \\
\text { implied either a humorous or critical } \\
\text { assertion.” (p. 12) }\end{array}$ & $\begin{array}{l}\text { "Isn’t it so nice to have guests here?” } \\
\text { about unpleasant guests. }\end{array}$ & $\begin{array}{l}\text { Lorraine: "Why don't you say you're } \\
\text { going to Jenny’s one more time?" } \\
\text { when sister repeatedly mentions she } \\
\text { is going to visit her friend Jenny. }\end{array}$ \\
\hline Hyperbole $^{2}$ & $\begin{array}{l}\text { “... speakers expressed their non-literal } \\
\text { meaning by exaggerating the reality of the } \\
\text { situation.” (p. 12) }\end{array}$ & "I was like the happiest person on earth.” & $\begin{array}{l}\text { Lorraine: “That's only you, Meg” } \\
\text { when sister is questioning Lorraine’s } \\
\text { friend about birth control. (Cameron, } \\
\text { Fox, et al., 2010) }\end{array}$ \\
\hline Understatement $^{2}$ & $\begin{array}{l}\text { “... speakers conveyed their ironic } \\
\text { messages by stating far less than was } \\
\text { obviously the case.” (p. 13) }\end{array}$ & $\begin{array}{l}\text { "James was a bit late with his rent,” when } \\
\text { in reality James was very late with his } \\
\text { rent. }\end{array}$ & No examples observed from youth. \\
\hline Literally False $^{3}$ & $\begin{array}{l}\text { An ironic utterance that is purposefully not } \\
\text { true to make a point. (p. 27) }\end{array}$ & $\begin{array}{l}\text { "I really appreciated waiting for you on } \\
\text { the street corner for an hour!" }\end{array}$ & $\begin{array}{l}\text { Lorraine: "You're a terrible person. } \\
\text { You're a terrible, terrible friend.” }\end{array}$ \\
\hline Literally True $^{3}$ & $\begin{array}{l}\text { An ironic utterance that is purposefully } \\
\text { true. (p. 27) }\end{array}$ & $\begin{array}{l}\text { A woman is asked how her blind date was } \\
\text { and she replies: "He had nice shoes." }\end{array}$ & $\begin{array}{l}\text { Idzel: "But I just want to have a dog” } \\
\text { in response to her father's comment } \\
\text { of being able to have children. }\end{array}$ \\
\hline Ambiguous $^{3}$ & $\begin{array}{l}\text { An ironic utterance used so that its "truth } \\
\text { value is difficult to determine." (p. 27) }\end{array}$ & "She is as smart as she is kind." & $\begin{array}{l}\text { Nu Dang: "Silly you, if everyone } \\
\text { copies me Thailand will be so much } \\
\text { better off" in reference to the type of } \\
\text { life she leads. }\end{array}$ \\
\hline Non-verbal $^{3}$ & $\begin{array}{l}\text { A form of irony in which no words are } \\
\text { used. (p. 27) }\end{array}$ & $\begin{array}{l}\text { When someone claps after an individual } \\
\text { makes a mistake. }\end{array}$ & $\begin{array}{l}\text { Lorraine and friend pump their fists, } \\
\text { mock-praising the friend's father. } \\
\text { (Cameron, Fox, et al., 2010) }\end{array}$ \\
\hline
\end{tabular}

\footnotetext{
${ }^{1}$ Dews et al. (1995)

${ }^{2}$ Gibbs (2000)

${ }^{3}$ Winner (1988)
} 
International Journal of Child, Youth and Family Studies (2013) 2: 189-208

Table 2. Some Functions of Irony

\begin{tabular}{|l|l|}
\hline \multicolumn{1}{|c|}{ Functions } & \multicolumn{1}{c|}{ Definition/Purpose } \\
\hline $\begin{array}{l}\text { Humor Function } \\
\text { (e.g., Dews et al., 1995) }\end{array}$ & $\begin{array}{l}\text { More humorous than literal language: yields pleasurable surprise in } \\
\text { the appreciation of the discrepancy between what is said and what is } \\
\text { meant. }\end{array}$ \\
\hline $\begin{array}{l}\text { Muting Function } \\
\text { (e.g., Dews et al., 1995) }\end{array}$ & $\begin{array}{l}\text { "Sugaring a pill”. Muffles the implied criticism (in the case of ironic } \\
\text { criticism) or implied compliment (ironic praise). Tones down (or up) } \\
\text { what is literally stated. }\end{array}$ \\
\hline $\begin{array}{l}\text { Face Saving Function } \\
\text { (e.g., Dews et al., 1995) }\end{array}$ & $\begin{array}{l}\text { Emotion control used to protect speaker and/or listener from offense, } \\
\text { to prevent the occurrence or escalation of social discomfort. }\end{array}$ \\
\hline $\begin{array}{l}\text { Affiliative Function } \\
\text { (Gibbs, 2000) }\end{array}$ & Bond speakers together and promote group solidarity. \\
\hline $\begin{array}{l}\text { Condemning Function } \\
\text { (Colston, 1997) }\end{array}$ & $\begin{array}{l}\text { "Salt a wound." Making an ironic criticism about a target or a } \\
\text { listener, to convey a negative attitude. }\end{array}$ \\
\hline
\end{tabular}

The goal of the current paper is to explore, in more detail, various types of irony used by youth and the functions that these examples of irony serve. Given that irony is an oblique form of humor and that paralinguistic information is important in its interpretation, we have analyzed videotaped spontaneous conversation in this investigation. Such methodology affords the use of more subtle, situational aspects of humor such as tone of voice, non-verbal cues, and forms of non-literal speech to interpret both the meaning of and the functions served by this form of speech. In this paper we explore the use of this non-direct speech to examine how youth use it to navigate tricky psychosocial waters and maintain their resilient functioning.

\section{Method}

\section{Participants}

Three of five female participants from a Negotiating Resilience project (described in more detail below) were selected for the analysis. We restricted our analysis to these specific three girls because their languages and cultures were most readily accessible to the authors. Girls are the focus of this research as they have been identified as an understudied population (Cunningham, 2006).

One girl had recently moved to live with her aunt and her aunt's young family in an impoverished community in eastern Canada. "Lorraine” turned 16 while we were working with her. The second girl, originally from Burma, had moved to a northern community in Thailand where she lived with her mother and older sister. Her father was deceased. "Nu Dang” was 15 years old when we worked with her. The third girl, 14 year-old "Idzel”, had recently moved with her refugee claimant family from Mexico to western Canada. She was living with her mother, father, younger sister, and grandmother. 
International Journal of Child, Youth and Family Studies (2013) 2: 189-208

\section{Data Collection}

The Negotiating Resilience Project employed an adaptation of a novel socio-ecological "Day in the Life (DITL)" methodology originally developed to observe relatively naturally occurring experiences of thriving toddler girls in their home contexts in diverse locations around the globe (Gillen et al., 2007). These adaptations of the DITL method were developed in the present research (Cameron, 2011; Cameron, Theron, Ungar, \& Liebenberg, 2011) to reflect the ecologies of resilient migrant adolescents in their diverse natural environments, again, around the globe. In each location, community youth workers selected participants whom they considered to be "at risk but doing well" in their somewhat adverse, economically challenging environments.

The goals of the methodological adaptation from our earlier work with toddlers were to enable the youths to have a voice in the selection of their Day's activities, to include interviews with them to enhance understanding of their perspectives, and to provide as many opportunities as possible for them to contribute to an understanding of their perceptions of their own experiences of adversity. Institutional ethics review boards, following accepted local practices, approved the procedures whilst the participants, their parents/guardians, and any bystanders gave informed consent for involvement. This is particularly critical when using such intimate visual methodologies as used here.

\section{Summary of Procedure}

This study involved multiple phases. First, youth advocating members of an advisory team selected youth who in their experience were thriving despite adverse circumstances. The youths and their families were approached and the adolescents were invited to participate in our study. Upon agreeing to participate, the teenagers in each culturally diverse location engaged in an intensive interview to discuss their perspectives on their strengths and the challenges they encountered in their daily lives. This interview was concluded with a photo elicitation request: They were given a disposable camera and asked to photograph in the upcoming week people, places, and things of importance to them.

The next convenient weekend, two researchers visited the teenager: One, a note taker and the other, a cameraperson who recorded up to 12 hours of the youth's Day. They also retrieved the disposable cameras. The researchers then viewed and shared the visual data and field notes with researchers in at least one of the other international sites; and they first, independently, and then together, compiled a half-hour composite video, that seemed to them to represent important interchanges during the Day that might exemplify the youths' strengths. This video was then shown to the youth, along with their elicited photographs, in order to engage them further in reflections on their lived experiences. Table 3 documents the stages of the research methodology. 
International Journal of Child, Youth and Family Studies (2013) 2: 189-208

Table 3. Summary of Methodology

\begin{tabular}{|c|c|c|}
\hline Research Phase & Researchers'Task & Research Activity \\
\hline 1. Initial recruitment & $\begin{array}{l}\text { Community workers } \\
\text { nominate youth; researchers } \\
\text { meet youth \& family, detail } \\
\text { procedures \& give informed } \\
\text { consent information }\end{array}$ & None \\
\hline $\begin{array}{l}\text { 2. Preliminary research } \\
\text { visit: Having obtained } \\
\text { consent, build rapport, } \\
\text { commence data collection }\end{array}$ & $\begin{array}{l}\text { Researchers obtain parental \& } \\
\text { youth consent, interview } \\
\text { youth, practice filming, } \\
\text { provide camera, decide } \\
\text { filming date }\end{array}$ & $\begin{array}{l}\text { Audiotape interviews, } \\
\text { acclimatising filming } \\
\text { practice, photo elicitation } \\
\text { instruction }\end{array}$ \\
\hline 3. Day in the life filming & $\begin{array}{l}\text { Local researchers film and } \\
\text { document full day }\end{array}$ & $\begin{array}{l}\text { Researchers film day; take } \\
\text { field notes, maps; retrieve } \\
\text { camera }\end{array}$ \\
\hline 4. Compilation selection & $\begin{array}{l}\text { Researchers select exemplary } \\
\text { interchanges from day for } \\
\text { half-hour compilation }\end{array}$ & $\begin{array}{l}\text { Local \& distal colleagues } \\
\text { independently select and then } \\
\text { agree on approximately six 5- } \\
\text { minute compilation segments }\end{array}$ \\
\hline 5. Iterative data collection & $\begin{array}{l}\text { Youth reflects on day's } \\
\text { compilation, elicited photos }\end{array}$ & $\begin{array}{l}\text { Local researchers tape } \\
\text { youth's reflections on film } \\
\text { clips, photos }\end{array}$ \\
\hline $\begin{array}{l}\text { 6. Data from above } \\
\text { research phases shared } \\
\text { among team; consultative } \\
\text { theme selection, analysis } \\
\text { \& dissemination }\end{array}$ & $\begin{array}{l}\text { Researchers compile local } \\
\text { data to share with } \\
\text { international team who } \\
\text { collaborate on thematic } \\
\text { analysis \& publication }\end{array}$ & $\begin{array}{l}\text { Subgroup teams conduct } \\
\text { protocol analyses of } \\
\text { interviews, field notes, } \\
\text { videos, photos, grounded in } \\
\text { data. Interpretation always } \\
\text { requires local input }\end{array}$ \\
\hline
\end{tabular}

\section{Transcription of Passages}

The field notes and transcriptions of the daily interactions were written in the language used by the participants: English in eastern Canada, Thai in Thailand, and Spanish in western Canada for the current study. These notes and transcriptions were then translated as necessary into English by at least one balanced-bilingual native speaker of both languages. We confirmed our interpretation of each episode of irony with either the local investigator or the participant herself. 
International Journal of Child, Youth and Family Studies (2013) 2: 189-208

\section{Data Analysis of Ironic Exchanges}

In our previous study of youth humor (E. L. Cameron, Fox, Anderson, \& C. A. Cameron, 2010) we scrutinized, from the interviews, video footage and field notes of one Canadian pair of adolescents (one boy and one girl), all instances of humor in their filmed Days. For the present study, these already identified instances of humor from Lorraine were examined to determine which of these humorous statements could be considered ironic. Likewise, ironic passages were identified by native speakers of Spanish and Thai, and the primary investigators of Idzel and Nu Dang's corpora respectively selected ironic examples from each. The authors collaboratively reached consensus on selected exemplary ironic utterances for in-depth analysis, and finally, the functions of these utterances were identified and explored in the context of the youths' complete corpus of exchanges that Day.

It is important to note that the ironic statements were identified line-by-line from the transcriptions and field notes. That is, each single ironic statement was identified and analyzed. Ironic episodes of longer duration were not explored. Ironic criticism, ironic compliment (praise), sarcasm, jocularity, rhetorical questions, hyperbole, understatement, literally false, literally true, ambiguous, and non-verbal were identified. Each instance identified in these data was matched with one category in the psychological taxonomy of irony reported in Table 1.

\section{Results}

All of the youth used irony in their spontaneous conversations and the following are some noteworthy examples.

\section{Canada}

Use of a muting rhetorical question: “Why don't you say you're going to Jenny's one more time?” (Lorraine to her sister whose son Lorraine is called on to care for). 


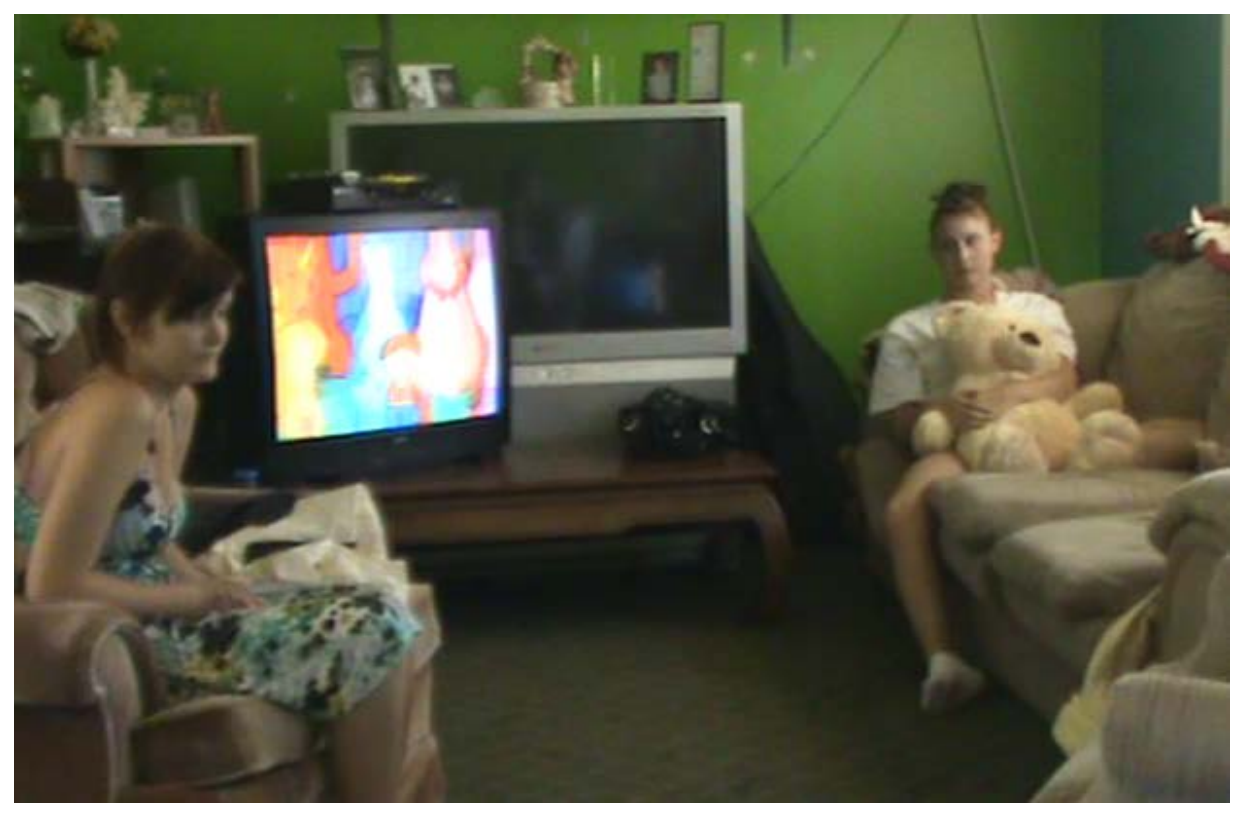

Figure 1. Grabbed still showing Lorraine (left) gentling sparring with her sister. "Grabbed still” images from the actual filmed footage are presented to give readers the sense of the dynamic nature of the target exchanges reported here.

Lorraine has recently moved to live with her aunt, who is her legal guardian. The household also includes her aunt's four children, her aunt's partner, and Lorraine's nephew, Michael. Michael's mother, Lorraine’s older sister, Megan, lives elsewhere. Lorraine's aunt has custody of Michael, and Megan has court-issued, supervised, visitation rights. Lorraine is sometimes called upon to supervise her sister's visits with her nephew if her aunt is unable to be present. This can strain the relations between Lorraine and Megan, when Lorraine is expected to monitor the care of her older sister's son.

Lorraine thus has a somewhat inverted sibling relationship with her sister and in the conversation that occurred before this target ironic utterance, Lorraine had implied resentment that Megan imposes on her to babysit. On this particular day, in addition to the needing supervision of her parenting, Megan also wants someone to babysit for her child. Instead of asking tactfully, she bluntly tells Lorraine to stay home with the baby so she can visit a friend. Lorraine's aunt would typically watch her nephew, but on this afternoon she is at a beach (where Lorraine would like to be) and Lorraine is volunteered to fulfill this responsibility. Lorraine has an exchange with Megan when Megan mentions several times that she is going to her friend Jenny's house, which will leave Lorraine stranded with the baby. Lorraine becomes increasingly annoyed and asks Megan, “Why don't you say you're going to Jenny's one more time?” Lorraine uses an indirect/non-literal query to respond to her sister. Figure 1 shows a grabbed still image of Lorraine gently sparring with her sister Megan. 
Following Gibbs (2000) we code this type of ironic utterance a rhetorical question, asking a question that humorously implies a critical perspective with no expectation of a rejoinder. She does not expect a response from her sister, but instead is ironically telling Megan that she is adding "insult to injury" and that by repeatedly mentioning going to Jenny's she is reinforcing the fact that Lorraine is going to be left to take care of the baby. Lorraine is showing her annoyance and frustration with her sister in a way that does not further put "salt in the wound" which more overt criticism of her sister might do.

This statement has a muting function that masks the implied criticism directed towards Megan. Lorraine expresses her frustration with her sister obliquely without directly saying that she is upset with her, thereby avoiding an altercation. Lorraine wants Megan to be aware that she is frustrated with having to stay home with her child but does not directly criticize, which could possibly exacerbate the situation. The rhetorical question mutes her expression of unhappiness with her sister and the situation Megan is putting her in, but provides Lorraine with a way to do so indirectly. By softening her criticism, Lorraine avoids a confrontation with an older sibling, thereby assuming her duties as a responsible sister and family member.

\section{A muted affiliative ironic compliment: “You're a terrible person. You're a terrible, terrible friend." (Lorraine to her friend on the telephone).}

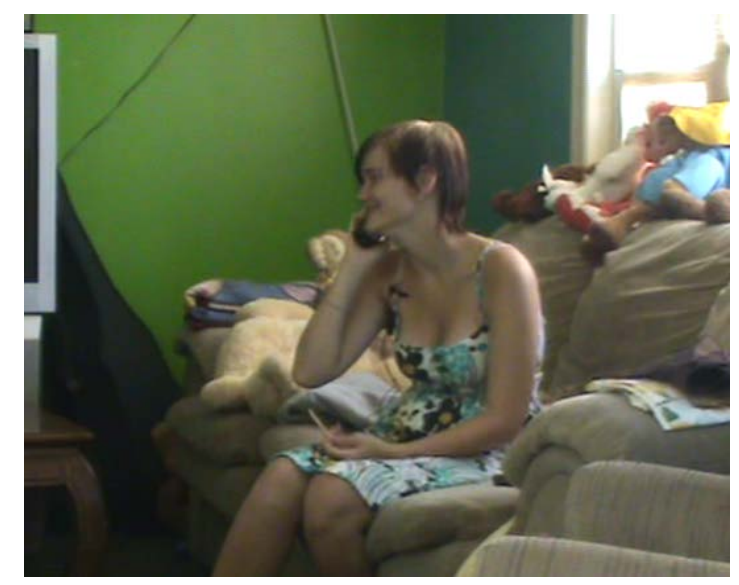

Figure 2. Grabbed still of Lorraine talking with her friend on the telephone.

Figure 2 shows a grabbed still image of Lorraine talking to her best friend on the phone, asking her if she would come to the lake with her that day. Lorraine's friend is unsure about accompanying Lorraine, but knows that not going would leave Lorraine companionless at the lake. After her friend tells Lorraine that she is not sure she will be going to the lake, Lorraine says, in a joking tone of voice, "You're a terrible person. You're a terrible, terrible friend". This statement is an ironic compliment. In a broad sense, Lorraine does not literally mean her friend is a terrible person, but instead implies that her friend is a good person and friend by saying the opposite. The nature of this compliment makes it clear in the tenor of the exchange between the 
friends that Lorraine values her friendship and wants to spend time at the beach with her. However, the meaning of this statement also is altered conditionally within the context of the conversation. While Lorraine is implying that her friend is a good person whom she wishes to spend the day with, her statement also implies that only a "terrible friend" would not accompany her to the lake. She does not, however, truly consider her friend to be a "terrible friend," making this statement ironic.

This instance of irony serves two functions: muting and affiliation. It is muting in that Lorraine diminishes what she truly feels for her friend by covering it up with what would sound on the surface to be an insult. Her friend knows this is not an insult and understands this from her relationship with Lorraine as well as from Lorraine's joking tone of voice. This example is affiliative because Lorraine is implying that as a good friend, she would come to the lake. Lorraine is expressing an "in-group” stance, which in this example consists of her and her friend, by indicating what would be appropriate intimate friendship behavior.

\section{Muted ironic criticism: “Nice one.” (Lorraine to her best friend at home).}

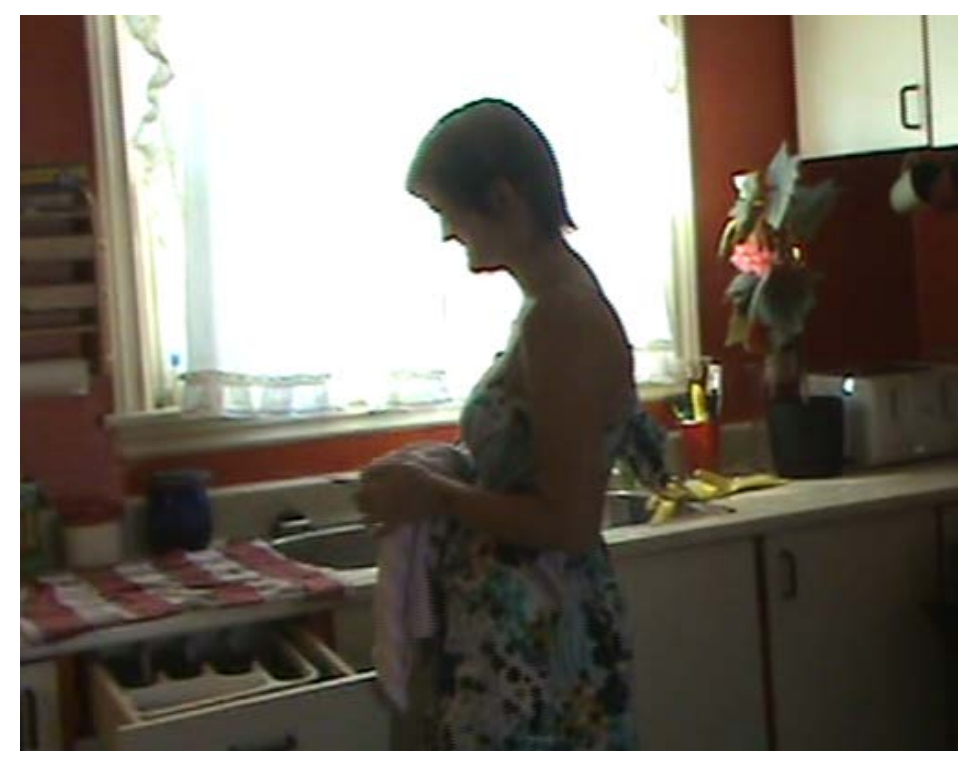

Figure 3. Grabbed still image of Lorraine congratulating her friend on her error.

Figure 3 shows an image of Lorraine when she and her friend are discussing playing the game Four-Square. Lorraine's friend mistakenly refers to the game Four-Square as foreplay, to which Lorraine replies “Nice one”. Lorraine points out her friend's mistake using ironic criticism. She realizes her friend's mistake but because of their close relationship, does not insult her. Lorraine does not literally mean that her friend did something good, but teases her friend for her verbal slip with gentle irony. 
The function of this statement is muting: “Nice one" in response to her friend's mistake is a way to tone down taunting her friend. Lorraine uses it in a way to tease her friend about her mistake. She also lets her friend know that she herself had made a similar mistake, telling her shortly afterwards, "I think I called it that the other day though when I was talking to the baby". By admitting to this, Lorraine makes it apparent that she does not really wish to criticize her friend, but instead to make light of her friend's mistake in a gentle way. Lorraine's comment could also be viewed as serving the affiliative function. Lorraine's comment on her friend's mistake, combined with her confession that she had also said foreplay a few days earlier, would facilitate the two becoming close through their common error.

\section{Thailand}

Use of muted ambiguous irony: "Silly you, if everyone copies me Thailand will be so much better off." (Nu Dang to her friends in preparation for a radio interview).

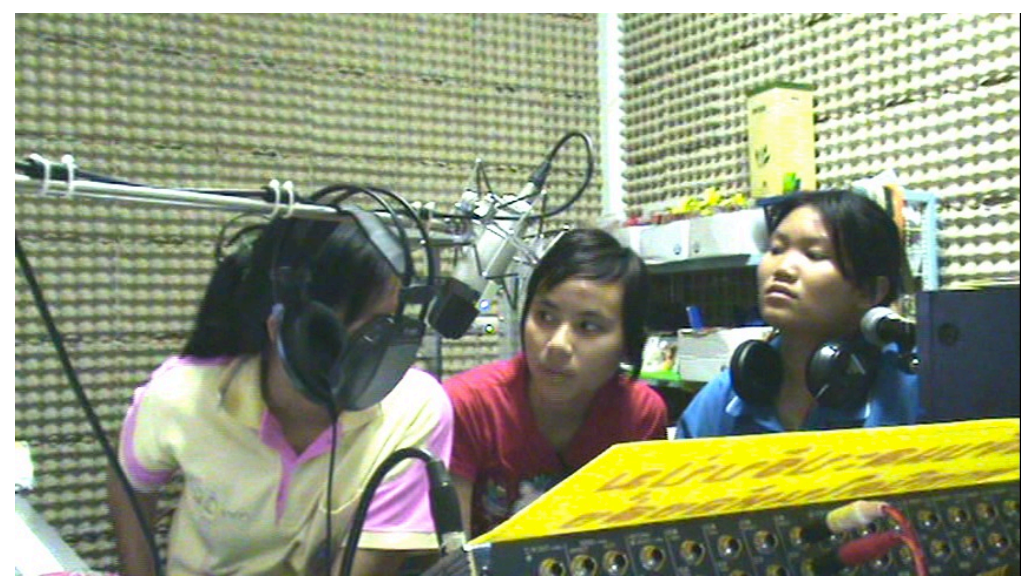

Figure 4. Grabbed still of Nu Dang being interviewed on air.

Nu Dang and her family were displaced from their home in Burma and now reside in a northern Thai community. She lives in a small apartment with her mother and older sister, rarely seeing her mother because of her mother's long work hours to support her family. Dang has a distant relationship with her mother, as she does not speak their Shan dialect any longer, so they have some difficulty communicating with each other. Dang's Shan ethnicity sometimes causes her to be subjected to ridicule at school; however, she persists in surmounting in her difficult situation in part through her academic successes, as well as, in her opinion, her ability to choose good friends who also, in her words, stay out of trouble.

In this episode in which Dang uses irony, she is in a community radio broadcast studio with two of her friends who are the hosts of a youth radio show, and are featuring Dang as their guest on a live broadcast for the day (see Figure 4). Dang questions her friends on what she should expect from the interview in order to prepare herself to answer their questions. She asks how she should go about telling about her life, and her friend replies lightly, "Just say 'nothing special, only eat sleep and watch $T V^{\prime \prime}$. Her friend's statement implies that Dang need not claim 
that she has a life of extraordinary activity and excitement. Dang's reply of "Silly you; if everyone copies me Thailand will be so much better off' indicates that reporting doing nothing special in her life would be no way to inspire others to overcome their adversities. It is an example of an ambiguous statement (Winner, 1988): The truth-value of Dang's statement is difficult to determine. Dang does not feel everyone would be better off leading a life that is nothing special; on the contrary, she feels that many would view this type of life as uninspiring. In this way, her ironic statement could be perceived as untrue. However, her life trajectory has so far kept Dang out of trouble, making it advantageous for her to continue her chosen path. Dang has been able to overcome much adversity in her life and may truly believe that if others follow her lead, they will be better off. Therefore, Dang could also be truthful in her modestly ironic statement. The uncertainty as to whether or not she is being literal with her comment makes the statement ambiguous.

This statement also serves a muting function to her main contention: Dang is deflecting an implied compliment. She is aware that she has strengths that have allowed her to thrive under challenging circumstances. Through her academic success and school engagements, Dang has overcome many life challenges and could be seen as a role model for other adolescents. However, she does not wish to be immodest. Humility is an important value in Dang's culture, and she is able to sustain this through the use of irony. The muting function on the statement provides Dang with a way to express her awareness of her success in life without seeming arrogant.

\section{Canada}

\section{Ironic literal truth: "But I just want to have a dog." (Idzel in conversation with family and two missionaries from the Mormon church).}

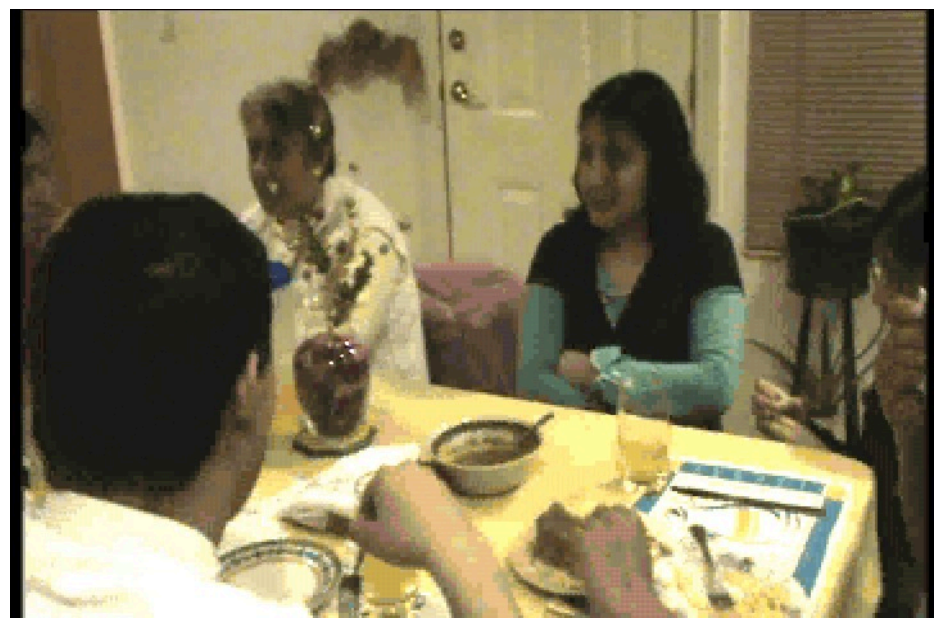

Figure 5. Grabbed still of Idzel at the dinner table engaging with LDS missionaries.

Idzel relocated with her family, which includes her mother, father, younger sister, and grandmother, all of whom are sustained by deeply held religious values and the strong support 
International Journal of Child, Youth and Family Studies (2013) 2: 189-208

from the (Mormon) Church of Latter-Day Saints (LDS). Idzel does not have many friends outside her home and church, and spends most of her Day with her family.

Idzel is working on an art project with her sister when two LDS missionaries join her family for a meal and subsequent Bible studies. After grace is said, Idzel joins the table to study with the elders (see Figure 5). Idzel questions them about their views of their work and their beliefs while her mother, grandmother, and father listen. Idzel asks the missionaries why God created people, to which, one missionary haplessly responds, "Just to see what would happen" while the other opines, “Because he loves you”. Idzel's father jumps in, offering as a stronger explanation: "So you can have children!". Her father is referring to Idzel's ability to bear children, or reproduce, which in its turn creates a somewhat embarrassing situation for Idzel to navigate. She is confronted with the topic of procreation at a table with young men present, and uses irony to deflect this embarrassment. She replies to her father, "But I just want to have a dog”. She plays on her father's words; although she knows that he technically means, "to bear children," Idzel uses "to have” as a form of possession.

We classify this statement as literally true (as would Winner, 1988): the statement is purposefully true. Idzel does want a dog, and ironically and incidentally points this out to her father, using this play on words. Idzel is aware of what her father literally meant with his statement, but by using her literally true but contrastive statement is able to deflect embarrassment while at the same time reminding her father that she would like to possess a dog. Idzel does not wish to discuss the subject of bearing children further, so she uses this situation as an opportunity to change the subject. This statement serves a humor function: Idzel's turn of phrase affords surprise value, bridging what is asked by what is returned. There is a startle value in Idzel's response to her father: While her father is referring to bearing children, Idzel unexpectedly responds in a humorous way to broach the subject of the family getting a dog. Idzel's use of irony allows her to deflect embarrassment in an uncomfortable situation by using a literally true but divergent statement to relieve embarrassment through its humorous function.

\section{Discussion}

Irony is a non-literal and indirect speech act delivered in many forms. In this study we have explored examples of ironic utterances made by resilient adolescent girls in their daily conversations, demonstrating both their comprehension and production of the non-literal speech identified as irony. We have provided examples of what we have coded as an ironic compliment, an ironic criticism, a rhetorical question, an ambiguous statement, and one that was coded as literally true. These youth use ironic utterances to achieve many ends, such as muting potentially confrontational statements, deflecting embarrassment, and affiliating with an interlocutor.

\section{Types of Irony}

Much recent work (e.g., Pexman \& Olineck, 2002; Pexman \& Glenwright, 2007;

Whalen \& Pexman, 2010) has focused on children's understanding of ironic compliments (e.g., saying "You're a terrible friend" when in fact the person is a fine friend) and ironic criticism (e.g., saying "You're a great friend" when in fact the person has just said something insulting), 
International Journal of Child, Youth and Family Studies (2013) 2: 189-208

but relatively little research has explored the broader range of types of irony used by children and youth. We have documented examples of ironic criticism and ironic compliments (Lorraine's "You're a terrible, terrible friend" and "Nice one”), but we have also observed various other types of irony. We demonstrated the use of a rhetorical question, as did Gibbs (2000) with adults, and literally true and ambiguous statements as Winner (1988) documented for children. We have provided an extensive list of types of irony in Table 1. It is worth noting that although some types of irony (e.g., ironic criticism) are more common than others, even early adolescents skillfully use a wide range of ironic forms.

\section{The Development of Humor and Irony Comprehension}

Previous research has demonstrated that although some forms of humor are performed and understood as early as the first year of life (e.g., Reddy, 2001; Loizou, 2007), and certainly by toddlerhood (McGhee, 1979), the comprehension of irony does not clearly emerge much before the age of 5 (for a review see Creusere, 1999). However, children may understand the muting function of irony before they are aware of its humorous function (Dews et al., 1996). Children's understanding of humor in irony appears at about 7 to 8 years of age (Harris \& Pexman, 2003). Thus, Pexman and Glenwright (2007) suggest a long course for the development of the full range of comprehension and production of irony.

That time course is extended in part because of the complex nature of irony. Pexman and Glenwright (2007) describe what must be understood in order for full comprehension of an ironic statement: an understanding of the speaker's belief, the speaker's non-literal meaning, and the speaker's attitude. Lack of any of these factors could lead to confusion and/or a lack of comprehension. The adolescent participants in the present study clearly understood irony, as described by Pexman and colleagues (Pexman \& Glenwright, 2007; Pexman, et al., 2005; Pexman \& Olineck, 2002) and understood it well enough to deploy it for multiple end goals. What accounts for the development from age 8 years to the teenage years? How do children come to understand irony and employ it toward social ends? These questions await targeted developmental investigation. One speculative answer may come from their developing cognitive and linguistic skills. The early adolescent youth we studied here are becoming abstract thinkers and problem solvers, as reflected in their articulated perceptions with respect to their situations during our interviews with them. For example, both Idzel and $\mathrm{Nu}$ Dang were able to describe their nuanced relationship toward religious practices and all three of our participants astutely characterized the foibles of parents, teachers, and peers. Such abstract thought makes possible an understanding of complex non-literal language. Thus another distinct possibility comes from the maturation of their social and cultural learning experiences (Pexman \& Glenwright, 2007). Exposure to and uptake on irony might be reciprocally faciliatory in coming to reflect upon and appreciate their own situations.

\section{Functions of Irony Use}

The social norms of daily conversation typically involve contributing prosocial utterances (saying “nice” things,) and not making disparaging remarks (Grice, 1989). Moreover, as indicated by Grice's (1989) conversational maxims, interlocutors follow rules in their speech acts, such as, for example, that the quality of their speech matches expectations. Irony clearly 
International Journal of Child, Youth and Family Studies (2013) 2: 189-208

violates this maxim, as determining the meaning of ironic utterances is not straightforward. Irony is a complex form of communication both because it apparently violates social norms for example, the conversational maxim of quality as described by Grice (1989) - and because it complicates the interpretation of interchanges as described above. So, why use irony? Irony in spontaneous conversation serves many functions, as described in Table 2:

1. Irony is used to add levity to a situation, such as when Idzel says she wants to own a dog, not bear a baby.

2. Irony also allows people to save face by speaking indirectly. Lorraine wants a good friend and she wants to help her friend save face in a potentially embarrassing (foreplay) exchange.

3. Irony mutes the contested discourses of our participants, as demonstrated in the majority of the samples described here.

That irony may serve a muting function has been somewhat controversial. For example, Dews et al. (1995) proposed a "tinge hypothesis" that argues that irony modulates the criticism conveyed in both ironic insults and ironic compliments. It is a way to tone down what is literally uttered. However, Colston (1997) argued that ironic statements do not serve to soften criticism, but instead they enhance it: He reported that ironic criticism enhanced condemnation rather than diluting it (Colston, 1997). To reconcile these disparate views, Pexman and Olineck (2002) hypothesized that for ironic insults the tinge function might only apply when one considers the listener's reception (i.e., the way they understand the statement) and might not apply when considering speaker intent alone (i.e., the motivation of the speaker which may or may not be obvious to a listener). Their research supported this hypothesis in that ironic insults were rated as more polite than literal insults, but they were also rated as more mocking and sarcastic than direct insults. On the other hand, ironic compliments were seen to be more mocking and less polite than direct compliments. According to Pexman and Olineck (2002), then, the tinge hypothesis only functions with ironic insults, whereas ironic compliments are seen to be less positive because they convey a more negative message than literal speech. The apparently contradictory finding about muting is akin to the seeming contradictory functions of affirmation and condemnation with irony. Irony can bond speakers together and promote group solidarity (see Gibbs, 2000), but again, see Colston (1997) on "salting the wound".

Thus, we suggest that despite the complications of the interpretation of ironic utterances, and notwithstanding the varied perspectives on the functions of the use of irony, these youths employed this form of speech because irony can be a beneficial communicative resource for navigating the potentially challenging psychosocial terrain of their particular circumstances.

\section{Irony and Humor Appreciation}

Apter's (1982, 2007) reversal theory of humor appreciation provides an integrative perspective within which we can understand irony. Apter argues that humor emerges due to both the synergy and the surprise evoked by verbal or physical acts. Thus, humor puts people in a playful (paratelic) state situating them to enjoy incongruity or comic synergy. There is comic synergy in ironic statements in that there is a distinction between appearance (what is said) and reality (what is meant). If we understand the incongruity of the statement and recognize that it is 
meant within a paratelic meta-motivational state then it could be experienced as funny. Further, according to Apter, superiority is experienced in the context of this synergy, which is a reason why the synergy might be found to be funny. The humor may involve disparagement or a feeling of superiority over others or our former selves. Apter's theory is consistent with many other researchers in highlighting the aggressive and disparaging nature of humor. We have previously reported, by way of contrast, but in accord with Socha and Kelly (1994), that the very young children we have studied did not use aggressive or disparaging humor (e.g., E. L. Cameron, Kennedy, \& C. A. Cameron, 2008; E. L. Cameron, Accorti Gamannossi, Gillen, \& C. A. Cameron, 2010), and here we extend this finding to resilient youth in conversation with friends and family. We do not observe irony used by either children or youth as a way to distance interlocutors, but rather as a way to maintain interpersonal connections, even in delicate negotiations.

In conclusion, the participants in these observational, naturalistic case studies are resilient youths who are thriving despite the risky environments in which they are functioning well. The data provided here support the notion that these resilient youths appear facile with the use of various forms of irony. We suggest that this complex verbal form is an important communicative resource that serves a protective function for them in the navigation of their challenging socio-emotional landscapes and thus should be considered a candidate promotive factor in the investigation of adolescent resilience. 
International Journal of Child, Youth and Family Studies (2013) 2: 189-208

\section{References}

Apter, M. J. (1982). The experience of motivation: The theory of psychological reversals. London: Academic Press.

Apter, M. J. (2007). Reversal theory: The dynamics of motivation, emotion, and personality (2nd ed.). Oxford: Oneworld Publications.

Cameron, C. A. (2011). “A day in the life”: A new methodology for investigating early childhood thriving and youth resilience around the globe. ISSBD Bulletin, 1, Ser. No. 59. 20-24.

Cameron, C. A., Theron, L., Tapanya, S., Li, C., Lau, C., Liebenberg, L., \& Ungar, M. (in press). Visual perspectives on majority world adolescent thriving. Journal of Research on Adolescence.

Cameron, C. A., Theron, L., Ungar, M., \& Liebenberg, L. (2011). Adapting visual methodologies to identify youth protective processes in negotiating resilience across cultures and contexts. Australian Community Psychologist, 23(2), 68-84.

Cameron, E. L., Accorti Gamannossi, B., Gillen, J., \& Cameron, C. A. (2010). Humour. In J. Gillen \& C. A. Cameron (Eds.), International perspectives on early childhood research: A Day in the Life (pp. 136-154). Houndmills, UK: Palgrave Macmillan.

Cameron, E. L., Fox, J. D., Anderson, M. S., \& Cameron, C. A. (2010). Resilient youths use humor to enhance socio-emotional functioning during "A Day in the Life”. Journal of Adolescent Research, 25(5), 716-742. doi: 10.1177/0743558410366595

Cameron, E. L., Kennedy, K., \& Cameron, C. A. (2008). “Let me show you a trick!”: A toddler's use of humor to explore, interpret, and negotiate her familial environment during “A Day in the Life”. Journal of Research in Childhood Education, 23, 5-18. doi: org/10.1080/02568540809594642

Colston, H. (1997). Salting a wound or sugaring a pill: The pragmatic functions of ironic criticism. Discourse Processes, 23, 24-53. doi:10.1080/01638539709544980

Creusere, M. A. (1999). Theories of adults' understanding and use of irony and sarcasm: Applications to and evidence from research with children. Developmental Review, 19(2), 213-262.

Cunningham, H. 2006. The invention of childhood. London: BBC Books.

Dews, S., Kaplan, J., \& Winner, E. (1995). Why not say it directly? The social functions of irony. Discourse Processes, 19(3), 347-367. doi: 10.1080/01638539509544922 
International Journal of Child, Youth and Family Studies (2013) 2: 189-208

Dews, S., Winner, E., Kaplan J., Rosenblatt, E., Hunt, M., Lim, K., et al. (1996). Children’s understanding of the meaning and functions of verbal irony. Child Development, 67(6), 3071-3085. doi: 10.1111/1467-8624.ep9706244848.

Gibbs Jr., R. W. (2000). Irony in talk among friends. Metaphor and Symbol, 15(1\&2), 5-27. doi: 10.1080/10926488.2000.9678862

Gillen, J., Cameron, C. A., Tapanya, S., Pinto, G., Hancock, R., Young, S., \& Accorti Gamannossi, B. (2007). "A Day in the Life”: Advancing a methodology for the cultural study of development and learning in early childhood. Early Child Development and Care, 177(2), 207-218. doi: 10.1080/03004430500393763

Grice, P. (1989). Studies in the way of words. Cambridge, MA: Harvard University Press.

Harris, M., \& Pexman, P. (2003). Children's perception of the social functions of irony. Discourse Processes, 36(3), 147-165. doi: 10.1207/S15326950DP3603_1

Loizou, E. (2007). Humor as a means of regulating one’s social self: Two infants with unique humorous personas. Early Child Development and Care, 177(2), 195-205. doi: 10.1080/03004430500387526

Martin, R. (2007). The psychology of humor. Burlington, MA: Elsevier Inc.

Martin, R. A., \& Kuiper, N. A. (1999). Daily occurrence of laughter: Relationships with age, gender and Type A personality. Humor: International Journal of Humor Research, 12(4), 355-384. doi: 0933-1719/99/012-0355

Masten, A. S., \& Wright, M. O. (2010). Resilience over the lifespan: Developmental perspectives on resistance, recovery and transformation. In J. W. Reich (Ed.), Handbook of adult resilience (pp. 213-237). New York: Guilford.

McGhee, P. (1979). Humor: Its origin and development. San Francisco: W. H. Freeman and Company.

Pexman, P. M., \& Glenwright, M. (2007). How do typically developing children grasp the meaning of verbal irony? Journal of Neurolinguistics, 20(2), 178-196.

Pexman, P. M., Glenwright, M., Krol, A., \& James, T. (2005). An acquired taste: Children’s perceptions of humor and teasing in verbal irony. Discourse Processes, 40(3), 259-288. doi: 10.1207/s15326950dp4003_5

Pexman, P. M., \& Olineck, K. M. (2002). Does sarcasm always sting? Investigating the impact of ironic insults and ironic complements. Discourse Processes, 33(3), 199-217. doi: 10.1207/S15326950DP3303_1 
International Journal of Child, Youth and Family Studies (2013) 2: 189-208

Reddy, V. (2001). Infant clowns: The interpersonal creation of humor in infancy. Enfance, 52(3), 247-256.

Sameroff, A. J. (2010). A unified theory of development: A dialectic integration of nature and nurture. Child Development, 81(1), 6-22. doi: 10.1111/j.1467-8624.2009.01378.x.

Socha, T. J., \& Kelly, B. (1994). Children making fun: Humorous communication, impression management, and moral development. Child Study Journal, 24(3), 237-252.

Ungar, M. (2011). The social ecology of resilience: Addressing contextual and cultural ambiguity of a nascent construct. American Journal of Orthopsychiatry, 81, 117. doi: 10.1111/j.1939-0025.2010.01067.x

Werner, E. E., \& Smith, R. S. (2001). Journeys from childhood to midlife: Risk resilience and recovery. Ithaca, NY, and London: Cornell University Press.

Whalen, J. M., \& Pexman, P. M. (2010). How do children respond to verbal irony in face-toface communication? The development of mode adoption across middle childhood. Discourse Processes, 47(5), 363-387. doi: 10.1080/01638530903347635

Winner, E. (1988). The point of words. London: Harvard University Press. 